\title{
El Admirarse como forma de enfrentar la nueva realidad americana
}

\author{
Raúl Álvarez, Moreno \\ Michigan State University
}

El artículo analiza el uso de la admiratio para presentar la nueva realidad americana a finales del siglo XV y durante el XVI. Tras explorar la riqueza semántica del término $y$ definirlo, se parte del mismo, como el primer estadio del proceso cognitivo del ser humano, cuyo objeto será una naturaleza, entendida como totalidad que incluye al hombre. La plasmación de lo admirable como parte del proceso cognitivo tiene también su lugar en el estudio. Pero será la transformación que supone el Renacimiento, la que convertirá a la admiratio en una función poética relacionada con el movere, y a la que América como inventio solucionaba el problema de la verosimilitud heredado de la Edad Media. El concepto será usado por nuestros autores, no ya para reflejar una fase del conocimiento, sino con una función claramente retórica: provocar un estado de ánimo en el lector para conseguir algo de él.

Palabras Clave: Invención de América, Retórica.

The article is a study of the use of admiratio to display the new American reality at the end of the fourteenth and into the fifteenth century. After exploring the semantic wealth of the term and defining it, we will present it as the first stage of the cognitive process of the human being, whose object will be Nature, understood as a whole entity in which men are included. The depiction of the admirable thing as a part of the cognitive process will also have its place in this study. But it is under the renovation that proposed the Renaissance, when admiratio turned into a poetic function related to that of movere, solving America as inventio the problem of verisimilitude inherited from the Middle Ages. Then, this concept will be used by our authors, not only to reflect a stage of knowledge, but with a clearly rhetorical function: to create a specific state of mind in the reader in order to obtain something from him.

KEYWORDS: America as invention. Rhetoric.

"El que no posee el don de maravillarse ni de entusiasmarse más le valdría estar muerto, porque sus ojos están cerrados".

Albert EINSTEIN

La llegada del hombre europeo a las tierras que hoy conocemos como América le puso ante la tesitura de tener que interactuar con una nueva realidad muy diferente a la suya. La propia condición dual del europeo de finales del siglo XV y principios del XVI en cuanto a pensamiento, medieval por un lado — espíritu religioso, de cruzada - y renacentista por otro 
- ciencia, cosmografía, comercio - sin duda condicionó el encuentro. Uno de los elementos que sufrió una mayor transformación con el Renacimiento fue el concepto de admiratio, que si bien formaba parte del universo medieval, fue reconfigurado por los humanistas desde los textos clásicos recién difundidos o editados, pasando a jugar un importante papel en las ideas literarias de los siglos XVI y XVII. ${ }^{1}$ Las páginas que siguen pretenden ofrecer una introducción al estudio de este concepto clave dentro de la literatura colonial hispanoamericana, no sólo por su influencia en la imagen que desde el principio se proyectó sobre las nuevas tierras y las posibilidades que ofreció al ser humano - europeo y también indígena-, de conocerse y re-conocerse a sí mismo en el Otro, sino también por el uso retórico que se hizo de él y las aportaciones que del mismo pudieran derivarse para la caracterización literaria de estos primeros textos hispanoamericanos.

De este modo y para aproximarnos al proceso de conocimiento y reconocimiento que inaugura el admirarse, vamos a empezar explorando en primer lugar los campos semánticos y léxicográficos del término a partir del siglo XVI, para intentar ofrecer una definición satisfactoria. Y en relación con esto, lo primero que nos llama la atención, cuando nos enfrentamos al concepto que nos ocupa, es el carácter polisémico, preñado de connotaciones, que tenía ya en la época del Descubrimiento. Por ejemplo, si consultamos el Diccionario de Autoridades ${ }^{2}$ nos encontramos en las definiciones de los mismos, una serie de rasgos que van a ser una constante en lo admirado: pasmarse de una cosa extraña; mirar una cosa con espanto de su calidad, de su valor o de su grandeza; el acto de ver y atender a una cosa no conocida, y de causa ignorada con espanto o particular observación; causar extrañeza algo por su primor, perfección o hermosura. Pero el admirarse también podrá surgir ante algo negativo - por ejemplo, el espanto causado por una matanza - o puede ser una reacción fingida, como nos muestra el ejemplo dado de la autoridad, que no es casual que provenga de un cronista de Indias, Solís. Este historiador, de acuerdo con el diccionario, en su Historia de Nueva España decía de los españoles que "afectaban admiración para disimular miedo". ${ }^{3}$ Por su parte, Covarrubias, en su Diccionario Etimológico (1611), añadirá otro dato importante, el de atributo humano que tiene una continuación dentro de un proceso más amplio de

1 Riley, Edward C.: "Aspectos del concepto de admiratio en la teoría literaria del Siglo de Oro". Studia Philologica: Homenaje a Dámaso Alonso, III. Gredos, Madrid, 1963, pags. 173-183.

2 Real Academia Española: Diccionario de Autoridades: Gredos, Madrid, 1963, pág. 1726.

3 Cf. el libro II, capítulo I. 
adquisición del conocimiento: "Entre las cualidades que se atribuyen al hombre, es ser admirativo; y de aquí resulta el inquirir, escudriñar y discurir cerca de lo que se le ofrece, hasta quietarse con el conocimiento de la verdad". ${ }^{4}$

En conclusión, podemos definir el admirarse como un efecto común y espontáneo ante lo nuevo, lo excepcional, lo inesperado, lo extremado cantidad—, lo excelente — calidad—, lo bello, lo sublime, o simplemente ante lo que no entendemos, y que se constituye en el primer estadio del proceso congnitivo. La admiración puede darse ante personas, cosas y palabras, ${ }^{5}$ y estaría relacionada con conceptos como el espanto, la reverencia y la curiosidad. ${ }^{6}$

Si empezamos centrando nuestra reflexión en torno al objeto del admirarse, descubrimos que éste va a ser la naturaleza, entendida en un sentido global griego clásico, como universo ordenado por leyes o cosmos. El hombre y el lenguaje formarían parte de ella, por lo que no se constituirían como objeto de admiración aparte, sino incluidos dentro de la misma, como bien parece entender Zavala para América: "the New World was perceived as populated by fantastic entities - fauna, flora, landscape, space, human beings -.". Para el pensamiento griego el admirarse era el primer paso de un proceso cognoscitivo que precisamente hacía al hombre sentirse parte de este marco general de la naturaleza: 1 . Se admira, 2. Descubre lo que es la cosa y la distingue de las demás. El admirarse le permitía tomar conciencia de su posición como individuo y de su libertad personal, situarse fuera de si mismo, de su círculo. La modernidad de este pensamiento estriba en que hacía al hombre activo, al entrar en comunicación con el cosmos del que él mismo es un reflejo en pequeña escala (microcosmos). Pero aún siendo parte de la naturaleza, el ser humano ocuparía un lugar especial, el de "despensero o fiel repartidor" como dirá Vives, lo que relaciona el admirarse con otro de los grandes temas del humanismo: el de la dignidad del hombre (Dignitas hominus vs. Miseria hominus).

4 Así en el Diccionario Etimológico de Covarrubias.

5 No solo el lenguaje no común es admirable. El Inca Garcilaso muestra la admiración que puede causar un saber práctico filológico, siendo éste una de las bases esgrimidas para la excelencia de sus Comentarios: “Y le mostré la pronunciación de este nombre y otros a viva voce.... De lo cual el catedrático y los demás religiosos que se hallaron a la plática se admiraron mucho”. Vega, Garcilaso de La: Obras completas. Ohio State University Press, Columbus, 1964, pág.56.

6 Riley, “Aspectos..”, pág.176.

7 Zavala, Iris: "El Nominalismo Imperial y sus monstruos en el Nuevo Mundo", en Zavala, Iris (Coord.): Discursos sobre la invención de América, Rodopi, Amsterdam, 1992, págs. 221- 233. 
Entre las principales cualidades que poseía el objeto admirable destacaba precisamente la inmanencia de su carácter ordenado y bien compuesto: "Porque no hay cosa más digna de admiración para los buenos y claros juicios que ver esta máquina y composición del mundo......la fortaleza de los polos sobre los cuales se mueven estas cosas con tan grande y admirable armonía". ${ }^{8}$ Es la misma sensación que va a experimentar Bernal Díaz ante la plaza de Tlatelulco: "Cuando llegamos a la gran plaza, que se dice el Tatelulco, como no habíamos visto tal cosa, quedamos admirados de.....y del gran concierto y regimiento que en todo tenían.". ${ }^{9}$ Así, la solicitud, el buen acabado, el orden aparecerán siempre como motivo de admiración, si bien es susceptible de ser causada además por todo lo contrario, por el caos, por la desmesura de una naturaleza amenazante y anárquica ${ }^{10} \mathrm{o}$ por algo tan trastocador como un terremoto. ${ }^{11}$ Otra cualidad que va a producir admiración será la presencia del novitas, la cualidad de ser nuevo y no visto u oído antes, admirándose el objeto por sorpresa o extrañamiento. ${ }^{12}$ También tamaño y cantidad serán características susceptibles de producir maravilla en el sujeto que las contempla - con las que se relacionarían los temas de la abundancia y la riqueza-, así como la belleza, la calidad o lo inexplicable, de lo que veremos ejemplos más adelante. ${ }^{13}$

En lo que concierne al admirarse y a su lugar dentro del proceso cognitivo, al originarse desde un contraste entre lo usual y lo inusual, se trataría de una primera reacción ante lo desconocido, de una primera forma de enfrentarnos a ello antes de todo método. ${ }^{14}$ Santo Tomás, comentando a Aristóteles, había mostrado cómo la admiratio procedía de la ignorancia, de la falta de conocimiento. Maravillarse sería el primer paso antes de empezar a filosofar, la primera causa que condujo a la filosofía, dentro de un proceso que empezaría por maravillarse y seguiría con el hacerse preguntas. ${ }^{15}$ Así, por ejemplo, frente a un Cortés, que busca referentes en Europa para lo que

8 Antonio de Torquemada, citado en Garrote Pérez, Francisco: Naturaleza y pensamiento en España en los siglos XVI y XVII, Ediciones Universidad de Salamanca, Salamanca, 1981, pág 41.

9 Díaz del Castillo, Bernal: Historia Verdadera de la Conquista de la Nueva España, Espasa Calpe, Madrid, 1997, pág.221.

10 Núñez Cabeza de Vaca, Álvar: Naufragios, Cátedra, Madrid, 1998, pág. 94.

11 Acosta, José de: Historia Natural de las India: Dastin, Madrid, 2002, pág. 204.

12 Díaz del Castillo, Historia Verdadera...pág.104.

13 Ibidem...pag. 394.

14 "The fascination inspired the thoughts and utterances of the pre-Socratics who were originally without method and somewhat dilettantish". Verheoeven, Cornelis: The Philosophy of Wonder, The Macmillan Company, New York, 1972, pág. 40. nificados.

15 Creo sobre este particular que no es una casualidad que en inglés wonder posea ambos sig- 
le produce admiración, o un Fernández de Oviedo que se maravilla ante las mareas y pregunta a los marineros sin una respuesta satisfactoria, pero sin intentar indagar más, estaría Acosta que usa la lógica para explicar lo que le admira, justificando su obra el hecho de llegar a estas explicaciones. ${ }^{16} \mathrm{El}$ ofrecerá una razón ante la maravillosa abundancia de naranjos en un área, o ante lo admirable del maguey o árbol de las maravillas, ${ }^{1{ }^{1}}$ sirviendo lo no explicable para inferir causas, e incluso usando la admiratio para cuestionar las opiniones de los clásicos: "Que muchos de ellos no quisieron creer que había tierra de esta parte, y lo que es más de maravillar, no faltó quien también negase haber acá este cielo que vemos". ${ }^{18}$ No es de extrañar que Acosta sea el único que explica las razones del ansia con que los españoles buscaron el oro o la plata ${ }^{19}$ aduciendo las causas físicas de su valor real como metales, si bien en un paralelismo con la caridad. Pero será el azogue al que su espíritu curioso y ávido de conocimiento dé más valor, dedicando a sus propiedades maravillosas incluso un capítulo entero de su obra (capítulo X). La misma actitud encontraremos en el Inca Garcilaso ante el admirarse, quien usa el proceso cognoscitivo para mostrar las limitaciones en la ciencia astronómica de los incas: "Admirábanse de los efectos, pero no procuraban buscar las causas, y así no trataron si había muchos cielos o no más de uno, no imaginaron de qué se causaba el crecer de la luna ni los movimientos de los demás planetas...”. ${ }^{20}$ Nuestro concepto supondría además la preponderancia defendida por los platónicos del sentido de la vista sobre el resto, no siendo ésta una afirmación filosóficamente baladí, al implicar la afirmación de que se empieza a conocer a través de los sentidos. Con todo, la admiración se producirá además de por la vista, —los indios salvajes ante los primeros Incas —,$^{21}$ a través de otros sentidos como el olfato - al oler el árbol del bálsamo- ${ }^{22} \mathrm{o}$ el oído — ante el rumor y zumbido de Tenochtitlán—. ${ }^{23}$ También, la admiración por lo desconocido —un volcán- y el tratar de satisfacerla, será lo que le abrirá una nueva ruta a Cortés hacia la capital

16 Cortés, Hernán: Cartas de Relación: Dastin, Madrid, 2000, pág. 103. Fernández de Oviedo, Gonzalo: Sumario de la Natural Historia de las Indias: Fondo de Cultura Económica, México, 1996, pág. 110 "Quien pasare adelante y llegare a entender las causas naturales de los efectos, tenía el ejercicio de buena filosofía” Acosta, Historia Natural ..., pág.146.

17 Ibidem, págs. 273 y 258.

18 Ibidem, pág. 59.

19 Ibidem, págs. 215 y 219.

20 De La Vega, Obras..., pág.83.

21 Ibidem, pág.31.

22 Acosta, Historia Natural...pág. 267.

23 Díaz del Castillo, Historia Verdadera...pág. 224. 
azteza, así como la primera reacción admirativa ante los pacientes de Cabeza de Vaca, será la que le impulse a realizar sus curaciones. ${ }^{24}$ De este modo, si por ejemplo tomamos como referente, el proceso de conocimiento y actuación, en la forma que lo hace Iris Zavala — nombrar, clasificar jerárquicamente, extraer riquezas - el admirarse sería un estadio primero, anterior a la representación del lenguaje que nombra a la realidad para apropiarse de ella. El propio Acosta se maravillará de que los indios, que tienen capacidad natural para admirarse ${ }^{25}$ creen un concepto - por ejemplo el de Dios-, pero que no continúen con el proceso lógico del conocimiento occidental y le den un nombre: "Que es cosa que mucho me ha maravillado que con tener esta noticia que digo, no tuviesen vocablo propio para nombrar a Dios" ${ }^{26}$ Otra cosa sería cómo se plasma esta admiración en los textos, lo que sí estaría más condicionado por el lenguaje y sus usos y que discutiremos más adelante. Ahora estaríamos con el sentimiento, la reacción espontánea ante la realidad, cualidad común a todos los seres humanos y con una mínima influencia de nuestra forma mentis. Desde luego, ni en este primer estadio es inevitable que haya una proyección de nuestros esquemas mentales, pero al menos el admirarse pondría al hombre en un estado anterior a lo que Zavala llama "logocentrismo de la civilización occidental" ${ }^{27}$ Hemos aceptado la capacidad de admirarse como cualidad humana universal, porque si bien es discutible si hay o no valores o representaciones universales, creo que la universalidad sí funciona al nivel en que estamos trabajando. ${ }^{28}$ Erasmo pensaba que había movimientos naturales al espíritu humano como el amor a la patria, el cariño a los hijos o a los padres, aunque hacía esto desde una clara posición occidental que para el Descubrimiento no se sostenía. Creo que la admiración no pertenece a este tipo de movimientos sino a otros menos tocados por el relativismo. El entender esta cualidad como algo común al ser humano - aunque pudiese haber variaciones en la forma de expresarla - permitiría el ejercicio de la Otredad, pudiéndose hacer énfasis no sólo en el que ve en los textos sino también en el que es visto, que a su

24 Cortés, Cartas..., págs. 113 y161.

25 Acosta, Historia Natural...pág. 373.

26 Ibidem, pág. 303.

27 Zavala, Nominalismo... pág. 227.

28 Los griegos concebían el maravillarse como manifestación de nuestra humanidad, como algo que nos diferenciaba de los animales, en conexión también con la risa y el humor, al poseer ambos el elemento común de la sorpresa. Al admirarse se opondrá más tarde el Nil admirari de los estoicos, que supone pasividad y que, por ejemplo, recrea Garcilaso de la Vega en su famosa epístola a Boscán: "El no maravillarse hombre de nada / Me parece, Boscán, ser una cosa / Que basta a darnos vida descansada...” De La Vega,: Obras..., pág. 143. 
vez ve y se admiraría ante la llegada de estos nuevos hombres para ellos maravillosos. ${ }^{29}$ En consecuencia, una de las aportaciones del estudio de la admiratio sería la contemplación de la alteridad antes incluso de su construcción, e incluso su funcionamiento como elemento de unión entre indios y españoles. En la línea de esto último iría la descripción del sentimiento de los presentes ante la ejecución de Caupolicán, en la que Ercilla alude a lo que sintieron los españoles, los indios y todos juntos: "Causó lástima y junto gran contento / al circunstante pueblo castellano / con grande admiración de todas gentes / y espanto de los bárbaros presentes". ${ }^{30}$

No conviene olvidar, sin embargo, que el pensamiento griego que llega a Europa en el siglo XVI está muy impregnado de cristianismo. De esta forma, el admirarse también se relacionaría con la contemplación de Dios, en quien se concentran las ideas de belleza y bondad que nos maravillan. Para la mayoría de los autores que tratamos, Dios y la naturaleza serán una misma cosa, por lo que la respuesta será la misma: admiración. ${ }^{31}$ No es otra la razón por la que Acosta señala en su Proemio que la finalidad de su obra era dar noticia de las cosas dignas de admiración en las que se mostraba Dios. ${ }^{32}$ Admirarse ante la naturaleza aproximaba más al ser humano a Dios, en la línea que expresa Merrim citando a Oviedo "the secrets of this great world of our Indies with always teach us new things, both to us here now and to those who come in the future to his contemplation and beautiful reading of the works of God". ${ }^{33}$ Las cosas que nos maravillan lo harían para llevar el mensaje de la divinidad o reflejar su obra y en ellas encontramos las mismas cualidades que encontramos en el Creador: belleza, variedad, abundancia..$^{34}$ Por otra parte, las obras de Dios, como por ejemplo el que la Tierra esté colgada en vacío sin que nada la sujete, nos causarán siempre más admiración que las obras de los hombres, porque ellas son inmunes al hastío "al revés de las obras humanas, que aunque están fabricadas con mucho artificio, en haciendo costumbre de mirarse no se tienen en nada, y

29 En este caso tendríamos que tener en cuenta cómo la llamada Profecía de la gente vestida influiría como prefiguración en la forma mentis del indígena, que pienso, deja lugar para el admirarse.

30 Ercilla, Alonso de: La Araucana, Castalia, Madrid, 1979, pág. 352.

31 Aunque Dios y la Naturaleza se identificarán en los textos, la identificación será de las acciones (Dios actúa por medio de la Naturaleza) y no por esencias como defiende el Panteísmo.

32 Acosta, Historia Natural...pág. 56.

33 Merrim, Stephanie: "The Apprehension of the New in Nature and Culture: Fernández de Oviedo's Sumario” en Jara, R. y Spadaccini, N. (Coord.): Re/Discovering Colonial Writing. University of Minnesota Press, Minneapolis, 1989, pág. 173.

34 En relación con este aspecto ver Cartagena, Teresa de: Arboleda de los enfermos. Admiración Operum Dey: Anejo XVI al Boletín de la RAE, Madrid, 1967. 
aún cuasi causan enfado". ${ }^{35}$ Eso no quita el que una obra técnica humana, como manifestación del conocimiento humano dado por Dios, sea también capaz de admirar. Como por ejemplo un puente, construido por los indios en Acosta, ${ }^{36}$ siempre más predispuesto a maravillarse ante los logros del Otro, o por los españoles en Cortés, ${ }^{37}$ como muestra de la pericia de sus mesnadas. También las maravillosas curas y milagros de Alvar Núñez serán vistos como un efecto de la intervención divina, como él mismo entiende "porque ya ellos tenían noticia de nosotros y cómo curábamos, y de las maravillas que nuestro señor con nosotros obraba" ${ }^{38}$ o el propio Acosta recoge al contar su historia. ${ }^{39}$ Ante lo ya expuesto, no debe sorprendernos que el comienzo de la contemplación para los místicos fuese el admirarse, y su ascensión comenzara en la fascinación que les producirían las cosas, las maravillas de la creación en las que veían a Dios.

Una vez analizado lexicográficamente y definido el concepto, dilucidado el objeto hacia el que se proyecta y su lugar dentro del proceso cognitivo universal, conviene pasar a su dimensión retórica, estudiando la forma en que, con otros fines además del conocimiento en sí, esta reacción fue expresada a través de la palabra en la literatura colonial, lo que convertiría al admirarse en un concepto preeminente dentro de la misma.

El principio de la admiración, que había sido establecido retóricamente en la antigüedad clásica por autores como Plinio, Quintiliano o Plutarco, es reelaborado por los teóricos renacentistas, que agregan a la lista de funciones poéticas (movere, docere, delectare) el causar admiración. ${ }^{40} \mathrm{Si}$ tomamos como perspectiva para el estudio de la literatura colonial la retórica de la época, la admiratio podría constituirse en un factor a tener en cuenta a la hora de dar fundamento literario a textos como las crónicas coloniales, en tanto y en cuanto fueron escritas con el objetivo de causar admiración en el lector. ${ }^{41}$ Por otro lado, el concepto de admiratio creaba un nuevo problema en su nueva reelaboración renacentista, que lo

35 Acosta, Historia Natural...págs. 67 y 68.

36 Ibidem, pág. 394.

37 Cortés, Cartas..., pág. 359

38 Núñez Cabeza de Vaca, Naufragios, pág. 151.

39 Acosta, Historia Natural...pág. 478.

40 A este hecho contribuyó sin duda la divulgación de la Poética de Aristóteles en el siglo XVI, que relacionaba la admiratio con la tragedia y la épica y aportaba el concepto clave de verdad poética. Riley, "Aspectos.. págs. 173 y 174.

41 Es la acertada propuesta que González Echevarría realiza en su artículo "Humanismo, Retórica y las Crónicas de la Conquista" en González Echevarría, Roberto: Isla a su vuelo fugitiva, Porrúa, Madrid, 1983, págs. 9-25. 
relaciona directamente con la verosimilitud. ${ }^{42}$ En su afán de separar lo históricamente cierto de lo fabuloso, unido durante la Edad Media, el humanismo se ve ante la tesitura de tener que conciliar lo admirable y lo verosímil, cuya contradicción no había sido hasta entonces problemática. Pero antes que otros escritores renacentistas en Europa, incluido el propio Cervantes, serán los primeros cronistas de Indias los que habrán de armonizar ambos conceptos de forma sistemática, lográndolo en general con resultados satisfactorios. La razón es que poseían algo que no habían tenido los renacentistas italianos ni los posteriores españoles: una inventio que lo hacía posible, un nuevo mundo recién descubierto y que debía ser contado. ${ }^{43}$ América ofrecía un nuevo espacio para la verosimilitud, un lugar donde la maravilla formaba parte de la realidad, donde la narración de lo admirable-verosimil era posible, y donde el prosista podía ejercer su obligación de reconciliar ambos conceptos con unas condiciones de eficacia que no habían disfrutado los escritores anteriores. El nuevo continente, como espacio admirativo, pasaba a ser en sí mismo una solución al problema humanista - tradicionalmente resuelto con la brujería, lo milagroso o el abuso de peripecias-, al ser una materia nueva y rara que no sobrepasaba el límite de lo probable, donde cabían los prodigios con una naturalidad inusitada, y donde los sucesos de caso y fortuna estaban más próximos a lo verosímil que, por ejemplo, en la novela bizantina. Las cosas que ocurrían en América eran admirables per se, al salirse de lo común pero sin dejar de guardar la semejanza de verdad. Esta necesidad de conciliación es uno de los motivos por el que nuestros autores, a pesar de jugar en una realidad que les ofrecía ventaja, siempre serán cautos al tocar la verosimilitud. De este modo, Oviedo desde su Dedicatoria se cuidará de vincular la novedad — que causa admiración — a la verdad, ${ }^{44}$ y Cortés al admirarse de Tlaxcala dirá que es algo "casi increíble", ${ }^{45}$ dejando claro que América es otro mundo, otra realidad donde se fuerza al límite lo maravilloso y que por eso mismo despierta la codicia del europeo: "Son cosas grandes y extrañas, y es otro mundo sin duda, que de sólo verle tenemos harta codicia los que a los confines de él estamos". ${ }^{46}$

42 Riley, “Aspectos.. pág.177.

43 No es extraño que Acosta vincule las dos grandes maravillas de su tiempo —navegarse el mar Oceáno y poder disfrutar los hombres en la zona tórrida de una clima no muy extremo- al descubrimiento de América. Acosta, Historia Natural...pág. 85.

44 Fernández de Oviedo, Sumario...pág. 80.

45 Cortés, Cartas..., pág. 103.

46 Ibidem, pág. 190. 
En cualquier caso, sería muy limitado pensar que lo admirativo en los discursos coloniales se restringe únicamente a lo que se dice - inventiosin pasar a la manera en que se dice. Si bien la materia en sí no necesitaba de grandes muestras de ingenio o artificios para causar admiración, vamos a encontrar un uso de la "terminología admirativa" ya vista, con el objeto de recrear el efecto sentido por el emisor, para que a su vez el receptor (lector o personaje), por empatía, pueda también sentirlo. Estaríamos entonces ante dos perspectivas del admirarse: la del emisor - las cosas causan admiración en él-y la del receptor —él intenta a su vez que causen admiración en el lector o un personaje de la obra, por ejemplo Moctezuma-, estando la primera subordinada a la segunda y ambas a un objetivo final persuasivo. ${ }^{47}$ En consecuencia, la admiración tendría en muchos de los textos una función retórica que la relacionaría con el conmover en el sentido de que crearía un estado de ánimo receptivo en el receptor para tratar de conseguir algo de él. ${ }^{48}$ De ahí la relación ya señalada con la verosimilitud, pues si se quería cautivar al receptor para aprovecharse del estado de ánimo suscitado, ya no era suficiente con presentarle algo admirable, sino que también era necesario que la historia presentada fuese "verdadera".

Asimismo, las ideas expuestas por Beatriz Pastor en su artículo "Cristobal Colón" nos confirmarían el uso referido del admirarse desde los primeros textos producidos. Si el almirante sabía a través de sus lecturas y sus prefiguraciones lo que iba a encontrar, si sólo es un "verificador e identificador", ${ }^{49}$ la admiración, que tiene la novedad e incluso la sorpresa como uno de sus constituyentes principales, no sería posible como expresión de un sentimiento, haciéndonos pensar en su uso menos lírico. Este razonamiento nos abriría la posibilidad de que Colón, al usar el admirarse como instrumento retórico, pudiera haberlo tomado de sus modelos, con la probable existencia de unos patrones a la hora de plasmar la admiratio. No es este artículo lugar para dilucidarlo, pero Pastor habla de cómo la admiración de Colón por la abundancia en el agua ya estaría en la escritura de Pierre d'Ailly, su

47 Riley, “Aspectos.. “ pág.175. El Renacimiento supuso en este sentido una mayor consideración del receptor, al que se intenta involucrar más en la obra de arte: concepto de Participación.

48 Las crónicas de Indias ejemplificarían muy bien este último paso, que tomaría forma con la Petición. Y ya en un nivel ficticio, la admiración podría incluso llegar a ser provocada intencionalmente en el indígena, para crearle un estado de estupefacción y apresarlo, como en la anécdota del indio que dio el nombre a Perú., De La Vega, Obras... pág. 12.

49 Pastor, Beatriz: "Cristóbal Colón y la definición del botín americano: La imagen de un mundo desconocido.", en Pastor, Beatriz (Coord.): El discurso narrativo de la conquista de América. Casa de las Américas, La Habana, 1983, pág. 20. 
modelo y Merrim sugiere que Oviedo refleja la misma actitud de maravillarse que Plinio..$^{50}$ Otro modelo que encontraremos a la hora de reflejar la admiración serán las novelas de caballería, llenas de sucesos que producían el maravillarse, pero cuyo modelo medieval de admiratio sin verosimilitud no satisfacía, como hemos visto, las nuevas aspiraciones renacentistas. ${ }^{51}$ Cervantes, consciente de ello, escribe el Quijote como un ataque contra este tipo de libros, especialmente contra su verosimilitud. Si lo que se admiraba de ellos eran los sucesos extraordinarios que allí ocurrían, al igual que Amadís por sus hazañas, Don Quijote causará admiración por lo disparatado de su armadura, sus costumbres y su lengua. Es un anacronismo andante, al igual que los indios para algunos cronistas. Estaríamos, pues, ante la admiración por lo grotesco, causada por lo maravilloso sin verosimilitud, que pasa a ser en el siglo XVI una fuente de lo cómico. ${ }^{52}$

En definitiva, la dimensión retórica del admirarse arriba expuesta nos lo presentaría ya más como un fenómeno político-persuasivo que como parte de lo cognoscitivo, desde el momento en que pasa de comunicar un sentimiento - la admiración - que lleva a buscar sus causas, a usarse como elemento persuasivo - dejar admirado— $-{ }^{53}$ Los autores, tratando de establecer un lenguaje de referencia externa que pudiese comunicar las maravillas naturales y humanas del Nuevo Mundo, empezarían a hacer funcionar el modelo epistemológico basado en la similitud o semejanza. ${ }^{54}$ Además de la hipérbole, la repetición, la variatio y otros recursos, el uso de la "terminología admirativa" se constituiría en la base de la expresión de lo admirable en los textos, con el objeto de mover al receptor a sentirlo. Con todo, habría variaciones en el uso y en los objetivos, que con una finalidad retórica encontraríamos asociadas al empleo de dicha terminología por los distintos

50 Merrim, “Apprehension...," pág. 174.

51 Bernal entre otros recurrirá al mismo: "Y aquella calzada tan derecha por nivel como iba a México, nos quedamos admirados, y decíamos que parecía a las cosas de encantamiento que cuentan en el libro de Amadís”. Díaz del Castillo, Bernal: Historia Verdadera...pág. 208.

52 Riley, Edward C.: “Aspectos...pag 179.

53 Se ve de forma muy clara este uso retórico en el Tercer Viaje de Colón, donde el mismo Almirante parece reconocer que se maravilla para causar un estado de predisposición en los reyes, y exponer sus razones frente a los ataques de sus enemigos: "Y en esto, por mis pecados o por mi salvación creo que será, fue puesto en aborrecimiento y dado impedimento a cuanto yo dezía y demandava, por lo cual acordé de venir a Vuestras Altezas y maravillarme de todo, y mostrarles la razón que en todo avía, y les dije de los pueblos que yo avía visto...", Colón, Cristobal: Textos y documentos completos: Alianza, Madrid, 1989, pág. 204.

54 Pastor, Cristóbal Colón... pág.19. Adorno, Rolena: "El sujeto colonial y la construcción cultural de la alteridad". Revista de Crítica Literaria Latinoamericana. XIV-28, Hanover, 1988, págs. 55-68. 
autores. Así, por ejemplo, habría sido el mismo Colón, como señalamos a propósito de las fuentes que pudo utilizar para este fin, el que habría sentado el precedente del uso del admirarse como estrategia para comercializar las nuevas tierras descubiertas. Sin descartar que el Almirante inicialmente se admirase de forma sincera ante lo que se le presentó a sus ojos - en contra de lo que se deduce del citado artículo de Pastor-, sin duda lo instrumentalizó de forma retórica para capitalizarlo. ${ }^{55} \mathrm{Si}$ leemos los textos del descubridor, nos damos cuenta que incluyen todos los elementos que hemos señalado como susceptibles de causar admiración: diversidad, cantidad (exuberancia natural, la abundancia), belleza, orden y armonía, riqueza, lo extraño y lo nuevo (animales y plantas), incluso lo excluido por anormal como el canibalismo de los caribes. Los ríos, la inteligencia de los indios, e incluso su generosidad y desprendimiento, pretenden causar admiración en el lector para atraerle, para excitar su deseo comercial, tapando al mismo tiempo el fracaso que para Colón significaba el no haber dado con las riquezas más evidentes y transportables que esperaba encontrar. ${ }^{56}$ Incluso el propio Las Casas, que en general toma partido por él, sembrará dudas a la hora de creer esa admiración: "Finally, he says, that if he who sees it is so full of wonder, how much more will it be for him who hears of it, and that nobody can believe it without seeing". ${ }^{57}$ Pero será la voz oficial de Oviedo, la que use de forma más sistemática el admirarse, para promocionar las Indias como un paraiso que debe ser explotado. Lo que Colón prevé en términos de cantidad, calidad y variedad, Oviedo lo ve: "Allí hay tanta cañafístola y tan excelente, que ya se trae a España en mucha cantidad, y desde ella se lleva y reparte por muchas partes del mundo; y vase aumentando tanto, que es cosa de admiración. En aquella isla hay muchos y muy ricos ingenios de azúcar, la cual es muy perfecta y buena". ${ }^{58}$ Oviedo incluso dará un paso más y, emocionado por su nuevo cargo y copiando a Colón, prometerá algo de lo que no sabe segura su existencia con el fin de admirar al Emperador, en este caso perlas: “...yo me tengo cuidado de las hacer buscar, y no me maravillo que allí se hallen asimismo". ${ }^{59}$ Tendrá tanto en cuenta a éste su primer receptor y

55 En contra de los testimonios de otros viajeros, recogidos por Morrison: "Visitors to San Salvador and the other Bahamian Islands find Columbus descriptions of nature extravagant, and are inclined to accuse him of laying it on thick to impress the Sovereign.”. Morrison, Samuel E.: Admiral of the Ocean Sea. A life of Christopher Columbus: Little, Brown and Company, Boston, 1991, pág. 234.

56 Colón, Textos...págs. 141-143.

57 Citado en Morrison, Admiral... pág. 272.

58 Fernández de Oviedo, Sumario...pág. 86.

59 Ibidem, pág. 268. 
su desmesura en el comer - llegó a causar gota a Carlos V—, que uno de los principales elementos admirativos de su obra estará vinculado a todo lo susceptible de servir como sustento. ${ }^{60}$ Un uso retórico similar hará Cortés, que emplea lo maravilloso para potenciar la cuantía de las cosas apartadas y asignadas como regalos al Emperador, con el objetivo de ofrecer un valor añadido a lo monetario: “...las cuales demás de su valor eran tales y tan maravillosas que consideradas por su novedad y extrañeza, no tenían precio ni es de creer que alguno de todos los príncipes del mundo de quien se tiene noticia las pudiese tener...". ${ }^{61}$

Otro aspecto retórico que será bastante común en las letras coloniales, será el empleo de la admiración con el objeto de construir al conquistador o sus hazañas como algo admirable. De este modo, Cortés se erige a sí mismo de forma muy hábil, no sólo como alguien admirable por sus proezas - ante los indios y los propios españoles - ${ }^{62}$ que además es capaz de producir el sentimiento en el enemigo para utilizarlo militarmente - por ejemplo en Moctezuma o sus embajadores-, sino que también se muestra como un ser humano capaz de sentir admiración por el mundo indio - Tenochtitlán—, lo que le ayuda a crear una relación simpatética con sus receptores. Su uso retórico de la admiratio quedará claramente confirmado en una magistral mezcla del nivel ficticio y del real, al fingirse admirado en un mensaje ante la actuación de Pánfilo de Narváez, a sabiendas de que él mismo no estaba legalmente al servicio del Emperador: "Pues él sabía que yo estaba en esta tierra en servicio de vuestra alteza, me maravillaba no me escribiese o enviase mensajero, haciéndome saber de su venida". ${ }^{63}$ Sin grandes diferencias con Cortés, la admiración pasará de individual a colectiva con Bernal: “...de lo cual nuestro capitán Cortés y todos nosotros, como no habíamos visto tal, nos admiramos dello". ${ }^{64} \mathrm{Si}$ añade Bernal una característica a lo admirable, que no ha sido traida a colación hasta ahora y me parece interesante resaltar, es su componente efímero al tratarse de las obras humanas:

Después de bien visto todo aquello, fuimos a la huerta e jardín, que fue cosa muy admirable vello y paseallo, que no me hartaba de mirar la diversidad de árboles y los olores que cada uno tenía, y andenes llenos de rosas y flores,...y un estanque de agua

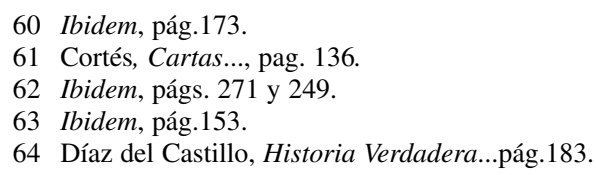


dulce y otracosa de ver...Digo otra vez que lo estuve mirando, que creí que en el mundo hobiese otras tierras descubiertas como éstas, porque en aquel tiempo no había Perú ni memoria dél. Agora todo está por el suelo, perdido, que no hay cosa en pie. ${ }^{65}$

El admirarse servirá a Bernal para intensificar nostálgicamente el contraste entre el pasado y el presente, entre el tiempo narrativo y el de escritura, resaltando el sentido de lo efímero que tiene el admirarse ante un paisaje aún sin transformar por el europeo, y que ya nunca más sería.

La propia construcción de nuestros conquistadores acabará recurriendo también a la admiratio en sus momentos de mayor desesperación. Es el caso de Colón, que en horas bajas tras no encontrar Catay ni Cipango, presenta en el Tercer Viaje lo que va descubriendo - por ejemplo las bocas del Orinoco - como algo capaz de maravillar a sus lectores per se más incluso que en el caso de estuviesemos ante una señal del Paraíso: "Y si de allí del Paraiso no sale parece aún mayor maravilla, porque no creo que se sepa en el mundo de río tan grande y tan hondo". ${ }^{66}$ Algo similar ocurrirá a un desdibujado Cortés en la Quinta Carta de Relación, que se vale de lo admirativo para intentar vender al receptor una nueva ciudad de la que sólo tiene noticias de oidas, como si fuese Tenochtitlán: "Y de ésta hay tan grandes nuevas, que es cosas de admiración lo que de ella se dice, que aunque falten los dos tercios, hace mucha ventaja a esta de México en riqueza, e iguálale en grandeza de pueblos y multitud de gente y policía de ella". ${ }^{67}$

No obstante, del admirarse también se realizará un aprovechamiento dialéctico más filantrópico, con el objeto del ayudar al indio. En esta línea, Las Casas fuerza su discurso hasta hacer lo admirable inverosimil con una finalidad retórica, para causar espanto en el receptor y moverle a reaccionar: "Todas las cosas que han acaecido en las Indias,...han sido tan admirables y tan no creíbles..., que parece haber añublado y puesto silencio y bastantes a poner olvido a todas cuantas por hazañosas que fuesen, en los siglos pasados se vieron y oyeron en el mundo". ${ }^{68}$ De este modo y en tanto que humanista, Las Casas estaría uniendo la admiratio con otro tema muy querido para el humanismo, la polémica entre los antiguos y los modernos, de una original manera que tiene como objetivo retórico el provocar una conmoción en el lector. Así, con el fin de producir un contraste, que es la

65 Ibidem, pág. 208.

66 Colón, Textos...pág. 216.

67 Cortés, Cartas..., pág. 427.

68 Las Casas, Bartolomé de: Brevísima Relación de la Destruición de las Indias: Cátedra, Madrid, 2001, pág. 69. 
base sobre la que se construye su discurso, el dominico describirá la admiración que le produce la abundancia de gentes y de bienes, para pasar a continuación a describir las matanzas:

Era cosa verdaderamente de admiración ver cuán poblada de pueblos, que cuasi duraban tres y cuatro leguas de luego, llenos de admirables frutales que causaba ser inmensa la gente. A estas gentes (porque era la tierra llana y rasa, que no podían asconderse en los montes,...) hízoles aquel tirano con sus tiranos compañeros que fueron con él, ....tantos daños, tantas matanzas, tantas crueldades, tantos captiverios e injusticias, que no podría lengua humana decirlo. ${ }^{69}$

Cabeza de Vaca se valdrá de la admiración en otro sentido, pero con el mismo objeto de proteger al indio. De esta forma, hablando de los indios fronterizos, recubrirá su teoría del buen tratamiento al indígena como mejor sistema para su conversión y asimilación al Imperio, con el efecto que este indulgente trato comporta:

Más como Dios nuestro Señor fue servido de traernos hasta ellos, comenzáronnos a temer y acatar como los pasados y aun algo más, de que no quedamos poco maravillados; por donde claramente se ve que estas gentes todas, para ser atraidas a ser cristianos y a obediencia de la imperial majestad, han de ser llevados con buen tratamiento, y que éste es camino muy cierto, y otro no. ${ }^{70}$

En cuanto a Acosta, elegirá la admiración que le causa el buen gobierno de los indios, para por medio de una paradoja — llama "esclavitud dichosa" al buen gobierno inca anterior a los españoles- esbozar una propuesta de autogobierno como el mejor sistema para los mismos. ${ }^{71}$

Otro aspecto relevante en relación con el uso que los autores hacen de la admiración, será el hecho de ser esgrimida como excusa, o más bien como coartada en la justificación de ciertos temas delicados o a la hora de incluir al Otro, aspecto esbozado por Adorno en "Literary Production and Suppression". El admirarse de forma negativa sería entonces una maniobra discursiva para hablar de cosas difíciles de tratar por las prescripciones impuestas sobre determinados temas, como los ritos de los nativos o sus prácticas sexuales, si bien se usará como argumento el hecho de que los griegos y romanos hiciesen cosas admirables semejantes o aún peores. ${ }^{72}$

69 Ibidem, pág.100.

70 Núñez Cabeza de Vaca, Naufragios..., pág. 199.

71 Acosta, Historia Natural... pág. 395.

72 Ibidem, pág. 298. 
Y ya para finalizar, los escritores se valdrían de la admiratio, como recurso metatextual que implicaría un propósito eminentemente retórico. A veces, lo admirable se presentará como soporte del tópico retórico de lo inefable, como en el caso de Cortés al narrar todo lo relacionado con el servicio de Moctezuma: "En lo del servicio de Mutezuma y de las cosas de admiración....que certifico a vuestra alteza que yo no sé por donde comenzar, que pueda acabar de decir alguna parte de ella". ${ }^{73}$ De la misma suerte lo emplea Ercilla para describir la ferocidad del combate singular entre Rengo y Tucapel, aunque tenía el precedente de ser un tópico muy usado en la épica:

\author{
Era cosa admirable la fiereza \\ De los dos en valor al mundo raros, \\ La providencia, el arte, la destreza, \\ Las entradas, heridas y reparos; \\ Tanto que temo ya de mi torpeza \\ No poder po sus términos contaros \\ La más reñida y singular batalla \\ Que en relación de bárbaros se halla. ${ }^{74}$
}

Bernal Díaz también relacionará la insuficiencia de los medios narrativos del cronista para describir lo que ve, con la admiración que suscita el enfrentamiento con una realidad distinta y para la que los clichés europeos no bastan. ${ }^{75}$ Su principal mérito será que amplía esta relación con el mundo de los sueños, juzgando los efectos de su propia escritura en el receptor: "Y no es de maravillar que yo aquí lo escriba desta manera, porque hay que ponderar mucho en ello, que no sé cómo lo cuente, ver cosas nunca oídas ni vistas y aún soñadas, como vimos". ${ }^{76}$

Otra utilización de lo admirable para referirse al propio texto será con el objeto de despertar el interés por lo que viene después, desempeñando el admirarse un cometido anunciador o catafórico. Es lo que realizará Garcilaso con la historia de Pedro Serrano, a la que se refiere inicialmente para despertar el interés en el lector en el capítulo VII del libro primero, pasando a contarla en el capítulo siguiente: "Y llegó a aquella isla, que es despoblada, inhabitable, sin agua ni leña, donde vivió siete años con industria y buena maña que tuvo para tener leña y agua y sacar fuego (es un caso

73 Cortés, Cartas..., pág. 144.

74 Ercilla, Araucana..., pág. 268.

75 Díaz del Castillo, Historia Verdadera..., pág.106.

76 Ibidem, pág. 208. 
historial de gran admiración, quizá lo diremos en otra parte)". ${ }^{77}$ Algo similar hace Acosta, al anunciar como algo maravilloso en el capítulo XX del Tercer Libro la ausencia de ciertos fenómenos meteorológicos en la costa de Perú, para pasar a explicarlo en el siguiente: "Lo tercero, en toda aquella costa nunca llueve, ni truena ni graniza ni nieva, que es cosa admirable". ${ }^{78}$ Pero será de nuevo el Inca Gracilazo ${ }^{79}$ quien mediante un uso excepcional del tópico de la modestia, lleve la admiratio a su refinamiento retórico, mediante la presentación de lo ausente - lo que no está en el texto y nunca escribió-, como admirable: "Y yo, como digo, las oí a mis mayores, aunque como muchacho con poca atención, que si entonces la tuviera pudiera ahora escribir otras muchas cosas de grande admiración". ${ }^{80}$

En conclusión, este trabajo ha tratado de ofrecer un estudio introductorio del uso de la admiratio por parte de los autores coloniales hispanoamericanos de finales del siglo XV y del XVI, para presentar la nueva realidad americana. Para ello, una vez explorada la riqueza semántica de la que he denominado "terminología del admirarse" (admiración, maravillarse, admirarse, a maravilla, maravilla) hemos llegado a una definición de la admiratio como un efecto espontáneo ante personas, cosas y palabras, que la convertiría en el primer estadio del proceso cognitivo del ser humano. Puesto que se trata de una cualidad universal, podría funcionar como elemento de unión al Otro, al ofrecer la posibilidad de contemplarlo antes de su construcción ideológica. El objeto del admirarse sería la naturaleza, entendida ésta como una totalidad que incluiría los tres elementos referidos, y que estaría dotada de una serie de cualidades susceptibles de ser admiradas: el orden, la novedad, el tamaño, la cantidad, la calidad, la belleza, lo inexplicable. El hecho de que teología y filosofía estuviesen todavía estrechamente vinculadas en el siglo XVI proyectará una visión de la naturaleza, como la manifestación de la divinidad, que habremos de tener en cuenta al reflejarse en los textos. Con todo, tendremos que separar las obras humanas y las divinas, por su diferente forma de causar admiración, pudiendo aparecer la maravilla ante las segundas como un primer estadio para la ascensión mística. La plasmación de lo admirable, como parte del proceso cognitivo, tendrá su lugar dentro de los textos coloniales que nos

77 De La Vega, Obras... pág.17.

78 Acosta, Historia Natural...pág. 193.

79 Ya hemos hablado anteriormente del uso del admirarse para presentar su libro como una obra singular, con un conocimiento práctico de las palabras del quechua que causa admiración.

80 De La Vega, Obras... pág. 10. 
ocupan, especialmente en autores como Acosta o el Inca Garcilaso. Pero la gran transformación que supone el Renacimiento para este concepto, al devenir la admiratio en una función poética más que se relacionaría con el movere, y al vincularse con la verosimilitud, tendrá enormes consecuencias para su recreación en los textos, desde que lo admirable no verdadero se constituye como cómico. Para la superación de este problema, América como inventio ofrece una solución, si bien la admiración superaría la materia para pasar a la forma —el cómo se cuenta América_, con un uso significativo de la "terminología admirativa" ya descrita. La diferencia es que no se usará ya para reflejar una fase del conocimiento, sino principalmente con una función claramente retórica a nivel real o ficticio: provocar un estado de ánimo admirativo en el lector o en un personaje de la obra para tratar de conseguir algo de él. Sería el principal uso del concepto en otros autores como Colón, que lo inauguraría, y al que seguirían Cortés, Bernal Díaz de Castillo, Oviedo o Las Casas, que emplearían su manifestación terminológica con fines tan diversos como, presentar las nuevas tierras como un lugar atractivo para su explotación, construirse o construir sus hazañas en el texto, defender al indio, superar la censura que garantizase la supervivencia del propio texto, o incluso como recurso metatextual para ayudar a conformarlo. 